\title{
Phasic Dopaminergic Transmission Increases NO Efflux in the Rat Dorsal Striatum via a Neuronal NOS and a Dopamine $D_{1 / 5}$ Receptor-Dependent Mechanism
}

\author{
Stephen Sammut*,', Alexander Dec', Darrion Mitchell', John Linardakis', Maria Ortiguela' and \\ Anthony R West' \\ 'Department of Neuroscience, The Chicago Medical School at Rosalind Franklin University of Medicine and Science, North Chicago, IL, USA
}

\begin{abstract}
Dysfunctional neurotransmission within striatal networks is believed to underlie the pathophysiology of several neurological and psychiatric disorders. Nitric oxide (NO)-producing interneurons have been shown to play a critical role in modulating striatal synaptic transmission. These interneurons receive synaptic contacts from midbrain dopamine (DA) neurons and may be regulated by DA receptor activation. In the current study, striatal $\mathrm{NO}$ efflux was measured in anesthetized male rats using an $\mathrm{NO}$-selective electrochemical microsensor and the role of DA in modulating NO synthase (NOS) activity was assessed during electrical or chemical (bicuculline) stimulation of the substantia nigra (SN). Electrical stimuli were patterned to approximate the natural single spike or burst firing activity of midbrain DA neurons. Electrical stimulation of the SN at low frequencies induced modest increases in striatal $N O$ efflux. In contrast, train stimulation of the SN robustly increased NO efflux in a stimulus intensity-dependent manner. NO efflux evoked by SN stimulation was similar in chloral hydrate- and urethane-anesthetized rats. The facilitatory effect of train stimulation on striatal $\mathrm{NO}$ efflux was transient and attenuated by systemic administration of the neuronal NOS inhibitor 7-nitroindazole and the nonselective NOS inhibitor methylene blue. Moreover, the increase in $\mathrm{NO}$ efflux observed during chemical and train stimulation of the SN was attenuated following systemic administration of the DA D I/5 receptor antagonist SCH 23390 . SCH 23390 also blocked NO efflux induced by systemic administration of the $D_{1 / 5}$ agonist SKF 81297 . These results indicate that neuronal NOS is activated in vivo by nigrostriatal DA cell burst firing via a DA $D_{1 / 5}$-like receptor-dependent mechanism.

Neuropsychopharmacology (2006) 3 I, 493-505. doi: I 0. I038/sj.npp. I 300826; published online I 3 July 2005
\end{abstract}

Keywords: nitric oxide; dopamine; dorsal striatum; $D_{1 / 5}$ receptor; neuronal NOS; Parkinson's disease

\section{INTRODUCTION}

Nitric oxide (NO) is an unstable free radical gas that functions as a neuromodulator in the central and peripheral nervous system (Boehning and Snyder, 2003). NO diffuses freely across cell membranes and modulates neurotransmission via its influence on target proteins in both pre- and postsynaptic elements. NO is synthesized from L-arginine in a reaction catalyzed by NO synthase (NOS) (Stuehr et al, 1991). Three isoforms of this enzyme have been purified, cloned, and sequenced: neuronal NOS (nNOS), inducible NOS (iNOS), and endothelial NOS (eNOS) (Nathan and Xie, 1994). In the striatum, NO is generated primarily via activation of nNOS which is localized to a subclass of

\footnotetext{
* Correspondence: Dr S Sammut, Department of Neuroscience, Rosalind Franklin University of Medicine and Science, 3333 Green Bay Rd, North Chicago, IL 60064, USA, Tel: +847 578 8658, Fax: + 847578 8515, E-mail: Stephen.Sammut@rosalindfranklin.edu Received 12 April 2005; revised I June 2005; accepted 3 June 2005 Online publication: 9 June 2005 at http://www.acnp.org/citations/ Npp06090505024 I/default.pdf
}

medium aspiny interneurons known to synthesize neuropeptide Y, somatostatin, and GABA (Bredt et al, 1990, 1991; Dawson et al, 1991; Kubota et al, 1993; Vincent, 1994). Considerable evidence has accumulated indicating that striatal NOS interneurons play a critical role in the integration of glutamatergic and dopaminergic neurotransmission within striatal neural networks (for a review, see Calabresi et al, 2000a; West et al, 2002).

Striatal nNOS interneurons receive synaptic contacts from the frontal cortex (Vuillet et al, 1989; Salin et al, 1990) and are activated by corticostriatal synaptic transmission (Kawaguchi, 1993; Berretta et al, 1997). Robust glutamatergic transmission is thought to activate striatal nNOS and NO signaling largely via the stimulation of NMDA receptors (Marin et al, 1992; East et al, 1996; Iravani et al, 1998; Crespi et al, 2001; Crespi and Rossetti, 2004), although other glutamatergic receptors may also be involved (Marin et al, 1992, 1993; Kendrick et al, 1996; Nishi et al, 2005). Evidence also exists indicating that activation of intrinsic cholinergic neurons may stimulate striatal nNOS activity via a muscarinic receptor-dependent 
mechanism (O'Shaughnessy and Bhoola, 1986; Consolo et al, 1999).

In addition to their glutamatergic inputs, nNOS interneurons have been shown to be heavily innervated by tyrosine hydroxylase $(\mathrm{TH})$ immunoreactive fibers (Fujiyama and Masuko, 1996; Hidaka and Totterdell, 2001). Early in situ hybridization studies indicated that NOS interneurons contain low levels of dopamine (DA) $\mathrm{D}_{1}$-like receptor mRNA (Le Moine et al, 1991). Moreover, recent double-labeling immunocytochemical studies have shown that the majority of striatal NOS/somatostatin-immunoreactive interneurons specifically localize $D_{5}$ receptors (Rivera et al, 2002). Additionally, the firing activity of electrophysiologically identified NOS interneurons is strongly enhanced by $\mathrm{D}_{1 / 5}$ DA receptor activation (Centonze et al, 2002). Given the proximity of glutamatergic and dopaminergic inputs on the NOS interneuron dendrites (Fujiyama and Masuko, 1996; Hidaka and Totterdell, 2001), it is likely that these afferents interact via presynaptic and/ or postsynaptic mechanisms to regulate striatal NOS activity. This is supported by histochemical evidence that both NMDA and $D_{1 / 5}$ receptor antagonists decrease NOS activity measured ex vivo (Morris et al, 1997). Interestingly, $\mathrm{D}_{1 / 5}$ receptor activation increases striatal tissue levels of the NO second messenger cGMP via an unknown mechanism (Altar et al, 1990). Given that striatal medium spiny neurons (MSNs) have been shown to contain high levels of guanylyl cyclase (GC) and other proteins associated with cGMP signal transduction pathways (Ariano, 1983), it is plausible that the increase in striatal cGMP levels observed by Altar et al following $\mathrm{D}_{1 / 5}$ agonist administration was an indirect effect of dopaminergic influences on the activity of nNOScontaining interneurons. Taken together, these studies indicate that DA neurotransmission may stimulate NOS neuron activity and striatal $\mathrm{NO}$ signaling directly via $\mathrm{D}_{1 / 5}$ receptor activation.

Considerable evidence exists indicating a role for NO-DA interactions in the generation of normal locomotor behavior and in pathophysiological conditions such as Parkinson's disease (PD) and drug abuse. Thus, behavioral studies have demonstrated that pharmacological blockade of NO signaling decreases basal locomotor activity (Stewart et al, 1994) and behaviors induced by substance $\mathrm{P}$ (Mancuso et al, 1994), $\mathrm{D}_{1}$ and $\mathrm{D}_{2}$ agonists (Starr and Starr, 1995), NMDA receptor antagonists (Deutsch et al, 1996), and a variety of abused drugs (see below). Interestingly, multiple measures of striatal NOS activity are depressed in 6-OHDAlesioned animals (de Vente et al, 2000; Sancesario et al, 2004) and patients with PD (Bockelmann et al, 1994; Eve et al, 1998), indicating that agents designed to target nitrergic signaling may be useful for the treatment of movement disorders.

In order to further characterize the interaction between dopaminergic and nitrergic transmission in the rat striatum, the current study examined the impact of electrical and chemical stimulation of the substantia nigra (SN) on NO efflux measured in vivo using an NO-selective electrochemical microsensor (Zhang, 2004). To our knowledge, the current study is the first to utilize NO microsensor recordings to examine the role of nigrostriatal pathways and DA receptor activation in regulating striatal $\mathrm{NO}$ synthesis in the intact animal.

\section{MATERIALS AND METHODS}

\section{Drugs}

Chloral hydrate, urethane, $R-(+)-\mathrm{SCH} 23390 \mathrm{HCl}(\mathrm{SCH}$ 23390), $R$-( + )-SKF $81297 \mathrm{HBr}$ (SKF 81297), 7-nitroindazole (7-NI), (-)-bicuculline methiodide (BIC), and Cremophor EL were purchased from Sigma (St Louis, MO). ( \pm )SNitroso- $N$-acetyl-penicillamine (SNAP) used for calibration of NO electrodes was obtained from World Precision Instruments (WPI, Sarasota, FL). Methylene blue (MB) was purchased from Fisher Scientific (Hanover Park, IL). All other reagents were of the highest grade commercially available.

\section{Subjects and Surgery}

Electrochemical measurements were made from male Sprague-Dawley (Harlan, Indianapolis, IN) rats weighing 245-400 g. Prior to experimentation, animals were housed two per cage under conditions of constant temperature (21$23^{\circ} \mathrm{C}$ ) and maintained on a $12: 12 \mathrm{~h}$ light/dark cycle with food and water available ad libitum. All animal procedures were approved by the Chicago Medical School Institutional Animal Care and Use Committee and adhere to the Guide for the Care and Use of Laboratory Animals published by the USPHS. Prior to surgery, animals were deeply anesthetized with chloral hydrate $(400 \mathrm{mg} / \mathrm{kg})$ or urethane $(1.5 \mathrm{~g} /$ $\mathrm{kg}$ ) and placed in a stereotaxic apparatus (Narashige International USA Inc., East Meadow, NY) so that the skull was set in a horizontal plane. After drilling a burr hole ( $\sim 2-3 \mathrm{~mm}$ in diameter) in the skull overlying the dorsal striatum (coordinates: -0.5 to $2.0 \mathrm{~mm}$ anterior from bregma, $2.0-3.5 \mathrm{~mm}$ lateral from the midline), the dura was resected and the microsensor or microdialysis probe was lowered into the striatum using a Narishige micromanipulator. All coordinates were derived from a rat brain stereotaxic atlas (Paxinos and Watson, 1986). The level of anesthesia was periodically verified via the hind limb compression reflex and maintained using supplemental administration of anesthesia as previously described (Floresco and Grace, 2003; West and Grace, 2004). Temperature was monitored using a rectal probe and maintained at $37-38^{\circ} \mathrm{C}$ with a heating pad (Fintronics Inc, Orange, CT).

\section{Electrical Stimulation}

In each experiment, twisted-pair bipolar stimulating electrodes (Plastics One, Roanoke, VA) were implanted into the SN (coordinates: $3.0-4.2 \mathrm{~mm}$ anterior to lambda, $1.5-2.0 \mathrm{~mm}$ lateral to midline, $7.5-8.5 \mathrm{~mm}$ ventral to the brain surface) ipsilateral to the micorsensor/dialysis probe. Electrical stimuli with durations of $500 \mu$ s and intensities between 0.5 and $1.0 \mathrm{~mA}$ were generated using a Grass stimulator (S88) and photoelectric constant current/stimulus isolation unit (PSIU6F, Grass Instruments, Quincy, MA) and delivered in single pulses $(2 \mathrm{~Hz})$ or as stimulus trains $(20 \mathrm{~Hz}, 800 \mathrm{~ms}$ train duration, $5 \mathrm{~s}$ intertrain interval (ITI)) for a duration of $100 \mathrm{~s}$. These stimulation parameters were derived from the studies of Hyland et al (2002) and were designed to approximate the natural burst firing (spikes per 
burst, intraburst frequency, and bursts per second) of high bursting DA neurons recorded in freely moving animals.

\section{In Vivo Microdialysis}

Concentric microdialysis probes (Bioanalytical Systems, West Lafayette, IN) having 3-4 mm of exposed membrane ( $225 \mu \mathrm{M}$ diameter, $6000 \mathrm{~d}$ permeability) were implanted into the dorsal striatum (coordinates: $0.7 \mathrm{~mm}$ anterior to bregma, $3.0 \mathrm{~mm}$ lateral to midline, $6.5 \mathrm{~mm}$ ventral to brain surface) using a Narashige micromanipulator (West and Grace, 2002). Following implantation, probes were perfused with artificial CSF (aCSF) containing (in mM) $145 \mathrm{NaCl}$, $2.7 \mathrm{KCl}, 1.0 \mathrm{MgCl}_{2}, 1.2 \mathrm{CaCl}_{2}, 2.0 \mathrm{NaH}_{2} \mathrm{PO}_{4}$, and 2.0 $\mathrm{Na}_{2} \mathrm{HPO}_{4}$ at a rate of $2 \mu \mathrm{L} / \mathrm{min}$ using a BAS microperfusion pump (Bioanalytical Systems, West Lafayette, IN). Microdialysis samples were collected every $10 \mathrm{~min}$ (represents one fraction) into $10 \mu \mathrm{l}$ of HPLC mobile phase to minimize degradation of DA and immediately analyzed by HPLC-EC (ESA, Inc., Chelmsford, MA) (Floresco et al, 2003). The HPLC system mobile phase consisted of $75 \mathrm{mM}$ sodium phosphate buffer ( $\mathrm{pH}=5.6), 25 \mu \mathrm{M}$ EDTA, $0.87 \mathrm{mM}$ SDS ion pairing reagent, $12.5 \%$ methanol, and $15 \%$ acetonitrile. The mobile phase flow rate was $1.0 \mathrm{ml} / \mathrm{min}$. DA was detected using an ESA Coulochem II detector equipped with a guard cell $(+300 \mathrm{mV})$ and a dual-electrode analytical cell (ESA 5014; $\mathrm{E} 1=-175 \mathrm{mV}, \mathrm{E} 2=+175 \mathrm{mV})$. The HPLC system was calibrated using external standards (detection limit of dialysate DA, $\sim 2 \mathrm{fmol}$ ).

\section{Electrochemical Detection of Nitric Oxide}

Striatal NO levels were determined using an NO selective, amperometric microsensor (Zhang, 2004; ISO-NOPF200, WPI, Sarasota, FL). The NO oxidation current (electrode potential of $0.85 \mathrm{~V}$ against a built in $\mathrm{Ag} / \mathrm{AgCl}$ reference electrode) was detected using a commercially available amplifier (Apollo 4000, WPI) and recorded using software applications (WPI) running on an Intel $^{\mathrm{TM}}$-based microcomputer with a data acquisition board interface (WPI). Prior to each experiment, the electrode was calibrated (Figure 1) in a temperature-controlled chamber (Diamond Instruments) using known solutions of NO generating compounds (Ohta et al, 1997; Zhang, 2004). Calibration curves were routinely constructed in order to determine the sensitivity of the electrode and confirm that the $\mathrm{NO}$ oxidation current exhibited a linear response to NO concentrations ranging from 0.6 to $48 \mathrm{nM}$ (Figure 1, inset). The selectivity of the NO microsensor for $\mathrm{NO}$ was also confirmed on occasion in vitro using known concentrations of DA and all other drugs $(\leqslant 1 \mu \mathrm{M})$ utilized in the current study.

\section{Drug Preparation and Administration}

Chloral hydrate, urethane, SCH 23390, SKF 81297, MB, and $\mathrm{BIC}$ were dissolved in physiological saline $(0.9 \%)$. 7-NI was dissolved in a $10 \%$ solution of Cremophor EL in saline $(0.9 \%)$ solution (Eblen et al, 1996). The effective dose of 7-NI was derived from the $\mathrm{ED}_{50}$ described by Kalisch et al (1996) $(25 \mathrm{mg} / 12.5 \mathrm{ml} / \mathrm{kg}$, i.p). In studies using MB, the dose of $10 \mathrm{mg} / \mathrm{kg}$ was derived from the range of doses used in previous studies (Volke et al, 1999; Harvey and Bester, 2000;

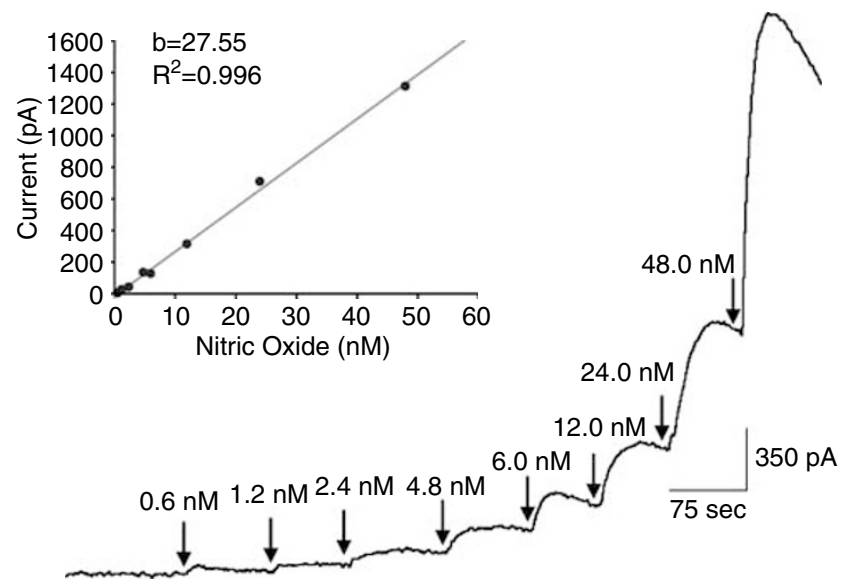

Figure I Calibration of the nitric oxide microsensor in vitro. Prior to implantation, electrodes were calibrated in a temperature-controlled $\left(37^{\circ} \mathrm{C}\right)$ chamber containing copper sulfate solution $(0.1 \mathrm{M})$. NO microsensor calibration curves (inset) were constructed from the $\mathrm{NO}$ oxidation current measurements generated from known concentrations of the $\mathrm{NO}$ donor S-nitroso-N-acetyl-penicillamine (SNAP, $100 \mu \mathrm{M}$ ) yielding $\mathrm{NO}$ concentrations of $0.6-48 \mathrm{nM}$ as indicated by arrows. Electrode sensitivity to exogenous $\mathrm{NO}$ ( $\mathrm{pA} / \mathrm{nM} \mathrm{NO}$ ) was derived from the slope of the regression line.

Wegener et al, 2000). The NO microelectrode response to SN stimulation was tested on average 2-3 times prior to drug administration, with stimulations separated by $15-$ 30 min from each other in order to obtain 2-3 consecutive responses that did not vary by $>20 \%$. The average of these measures was considered as the control response to which responses following drug administration were compared. Effective doses of SCH $23390(100,500 \mu \mathrm{g} / \mathrm{kg}$, i.p.) and SKF $81297(50 \mu \mathrm{g} / \mathrm{ml} / \mathrm{kg}$, i.v $)$ were derived from the range previously reported in the literature (Gonon, 1997; Morris et al, 1997; Reynolds et al, 2001; Floresco and Grace, 2003; Brady and O'Donnell, 2004). In studies using SKF 81297, drug was administered intravenously (via a lateral tail vein) after obtaining $150 \mathrm{~s}$ of basal activity. In these studies, the response to SKF 81297 was recorded for 20-30 min, during which NO oxidation current levels generally returned towards baseline. In some experiments, SCH 23390 was administered systemically (i.p.) as described above, and the impact of SKF 81297 on NO efflux was reassessed approximately $20 \mathrm{~min}$ later. No electrical stimulation was applied during the drug testing phase. BIC was administered via a $25 \mathrm{G}$ cannula, implanted into the midbrain with the tip targeted just dorsal to the SN, utilizing a BAS MD1001 syringe drive system (Bioanalytical Systems, West Lafayette, IN). A total of $200 \mathrm{ng} / \mu \mathrm{L}$ of $\mathrm{BIC} /$ saline was administered over $2 \mathrm{~min}$ at a rate of $0.5 \mu \mathrm{l} / \mathrm{min}$. In some experiments, SCH $23390(500 \mu \mathrm{g} / \mathrm{kg}$ i.p.) was administered approximately $20 \mathrm{~min}$ prior to the BIC injection.

\section{Histology}

Following experimentation, animals were deeply anesthetized and perfused transcardially with ice-cold saline followed by $10 \%$ formalin in buffered phosphate (PB) (EMS, Hatfield, PA). Brains were then removed and postfixed in $10 \%$ formalin/PB for at least 1 week. Next, brains were immersed in PBS/sucrose solution (30\%) until 
saturated and sectioned into $50 \mu \mathrm{m}$ coronal slices, mounted, and stained with Neutral red/Cresyl Violet $(10: 1)$ solution to enable histological determination of stimulating electrode and NO sensor or dialysis probe sites (Figure 2a, b).

\section{Data Analysis}

In microdialysis studies, chromatograph peak heights $(\mathrm{cm})$ corresponding to both standards and dialysate-derived DA were converted into $\mathrm{fmol} / \mu \mathrm{l}$ values using a spreadsheet program (Floresco et al, 2003). HPLC-EC calibration (nA/ ng) for a given analyte was determined daily by injecting $100-200 \mathrm{pg}$ of standard onto the HPLC (ESA, Inc., Chelmsford, MA). The average of the three stable fractions immediately preceding the experimental manipulation and
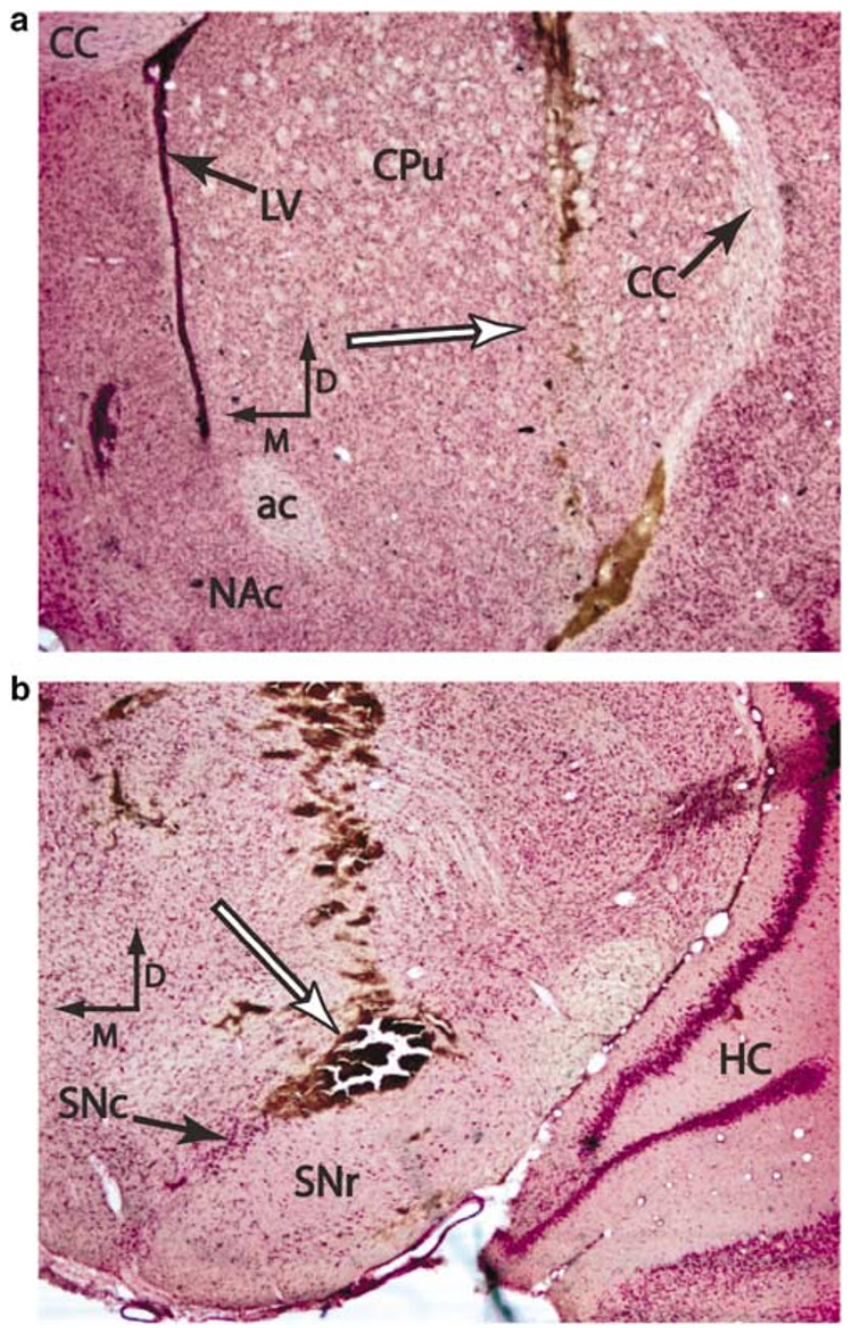

Figure 2 Position of implants in the dorsal striatum and SN. (a) An NO microsensor or microdialysis probe was implanted into the striatum and $\mathrm{NO}$ oxidation current or extracellular DA levels were determined prior to, during, and after SN stimulation. (b) A stimulating electrode was implanted into the SN or MFB (see Materials and Methods). The white arrows indicate the recording electrode track in the anterior dorsal striatum (a) and stimulating electrode termination point (b). ac, anterior commissure; SNc, substantia nigra compacta; $\mathrm{SNr}$, substantia nigra pars reticulata; LV, lateral ventrical; CC, corpus callosum; HC, hippocampus; D, dorsal; M, medial. not varying by $>20 \%$ in analyte concentration $(\mathrm{fmol} / \mu \mathrm{l})$ was defined as the control (100\%). Following baseline determination, electrical stimulation was performed for one fraction and DA levels were monitored for 20-30 min poststimulation. Data are expressed as percent of control (not corrected for in vitro probe recovery).

In experiments using $\mathrm{NO}$ microsensors, the $\mathrm{NO}$ oxidation current (pA) was allowed to stabilize for at least $150 \mathrm{~s}$ prior to stimulation. The NO oxidation current recorded $(50 \mathrm{~Hz}$ sampling frequency) during the last $30 \mathrm{~s}$ of the prestimulation period was then averaged using Apollo 4000 software applications (WPI) and subtracted from the mean NO oxidation current recorded during the last $30 \mathrm{~s}$ of the stimulation period. In experiments where SKF 81297 was administered systemically, the NO oxidation current was measured as the average of a $100 \mathrm{~s}$ period recorded $150 \mathrm{~s}$ after the start of SKF 81297 injection, minus the average of the last $30 \mathrm{~s}$ recorded prior to the injection of the drug. Using these methods, the peak increase in NO oxidation current was consistently measured across animals in an unbiased manner. Data are expressed as concentration NO $(\mathrm{nM})$ as determined from in vitro calibration curves. The statistical significance of drug- and stimulation-induced changes in NO oxidation current was assessed using either an unpaired or paired $t$-test or one/two-way analysis of variance (ANOVA) with repeated measures (RM) as indicated (Sigma Stat, Jandel). Additionally, either Dunnet's multiple comparisons test, Bonferroni, or Tukey post hoc tests was used as indicated to determine which group(s) contributed to overall differences seen with ANOVA. Data pertaining to DA and NO efflux are graphically represented as the mean percent of control and $\mathrm{nM} \pm \mathrm{SEM}$, respectively.

\section{RESULTS}

\section{Electrode, Microdialysis Probe, and Cannula Placements}

In experiments involving electrical stimulation of the $\mathrm{SN}$, identified stimulating electrode tips were confirmed to lie within the SN or medial forebrain bundle between 2.96 and $4.7 \mathrm{~mm}$ anterior to the interaural line, 1.5 and $3.0 \mathrm{~mm}$ lateral to the midline, and 7.5 and $9.0 \mathrm{~mm}$ ventral to the surface of the skull (Figure 2b; Paxinos and Watson, 1986). In experiments involving chemical stimulation of the $\mathrm{SN}$, all infusion cannula tips were confirmed to lie within the SN between 3.2 and $4.2 \mathrm{~mm}$ anterior to the interaural line, 1.5 and $2.4 \mathrm{~mm}$ lateral to the midline, and 7.0 and $7.8 \mathrm{~mm}$ ventral to the surface of the skull (Paxinos and Watson, 1986). Identified placements for dialysis probes/NO electrodes implanted into the striatum (Figure 2a) were verified to lie between $0.8 \mathrm{~mm}$ posterior and $1.7 \mathrm{~mm}$ anterior to bregma, 1.5 and $4.5 \mathrm{~mm}$ lateral to the midline, and 3.8 and $7.6 \mathrm{~mm}$ ventral to dural surface (Paxinos and Watson, $1986)$. As the active surface of the NO electrodes ( $\sim 4$ $5 \mathrm{~mm})$ and microdialysis probes $(\sim 3-4 \mathrm{~mm})$ used in this study was relatively large, it is likely that NO and DA efflux were sampled across several dorsal-ventral striatal subregions.

Interestingly, both electrical train $(20 \mathrm{~Hz})$ and chemical stimulation (BIC infusions) of the SN were usually observed to induce bilateral whisker twitches (more pronounced on ipsilateral side), which were time-locked to the stimulus 
train or drug infusion. We believe the observed response was specific to stimulation in or proximal to the $\mathrm{SN}$ because: (1) electrodes that were not placed in the $\mathrm{SN}$ showed a whisker twitch response that was greatly reduced or absent, (2) the same twitching response was observed during chemical stimulation indicating that it was not induced by current spread to the cerebral peduncle or activation of fibers of passage in the midbrain, (3) during chemical stimulation the whisker twitch did not appear immediately, but only after NO levels were observed to rise substantially from baseline, (4) the response disappeared once the NO levels began to approach prestimulation levels. Our qualitative observations correlating stimulus-induced whisker twitch responses with histological assessments of electrode/cannula termination sites indicate that this response is an important and useful sign that the electrode/cannula was accurately implanted in the SN region.

\section{Impact of Electrical Stimulation of the SN on Striatal NO and DA Efflux}

To characterize the potential role of DA transmission in modulating striatal NO synthesis, afferents from the SN were activated using electrical stimulation (500-1000 $\mu \mathrm{A})$ delivered for $100 \mathrm{~s}$ as low frequency single pulses $(2 \mathrm{~Hz}$, $0.5 \mathrm{~ms}$ ), or as trains of high-frequency stimulation patterned to approximate the natural burst firing activity of midbrain DA neurons $(20 \mathrm{~Hz}, 800 \mathrm{~ms}$ train duration, $5 \mathrm{~s}$ ITI, see Materials and Methods). High-frequency SN stimulation $(1000 \mu \mathrm{A})$ significantly increased striatal DA efflux over basal levels by $139 \pm 42 \%$ (Figure $3 \mathrm{a} ; p<0.05$ ). The observed stimulation-induced increase in DA efflux typically returned to baseline $10-20 \mathrm{~min}$ after cessation of stimulation. Basal striatal extracellular DA levels were $2.40+0.6 \mathrm{fmol} / \mu \mathrm{l}$.

These studies also examined the impact of stimulation amplitude $(500,750,1000 \mu \mathrm{A})$ on NO efflux evoked during low $(2 \mathrm{~Hz})$ and high $(20 \mathrm{~Hz})$ frequency stimulation of the $\mathrm{SN}$. The results of these studies indicated that NO efflux evoked during train stimulation $(20 \mathrm{~Hz})$ was significantly greater than $\mathrm{NO}$ evoked at the same current intensities during low-frequency stimulation $(2 \mathrm{~Hz})$ of the SN (Figure $3 b, c ; p<0.05)$. The effect of different frequencies of stimulation also depended on the intensity of current delivered. Thus, there was a significant interaction between frequency and current (Figure 3c; $p<0.05$ ). Electrical stimulation of the $\mathrm{SN}$ at a low frequency $(2 \mathrm{~Hz}) \mathrm{did}$ not affect striatal NO efflux in a current intensity-dependent manner (Figure $3 c ; p>0.05$ ). In contrast, train stimulation $(20 \mathrm{~Hz})$ significantly increased striatal NO efflux at all stimulus intensities examined in an intensity-dependent manner (Figure 3c; $p<0.05$ ). NO efflux was significantly higher following train stimulation at 750 and $1000 \mu \mathrm{A}$ (Figure $3 c ; p<0.01, p<0.001$ ) as compared to that evoked at $500 \mu \mathrm{A}$. No significant differences were observed between NO efflux evoked at 750 and $1000 \mu \mathrm{A}(p>0.05)$.

\section{Impact of Repeated Stimulation and Anesthesia on NO Release}

The facilitatory effect of high-frequency SN stimulation $(20 \mathrm{~Hz}, 800 \mathrm{~ms}$ train duration, $5 \mathrm{~s}$ ITI, $750 \mu \mathrm{A})$ on striatal NO a
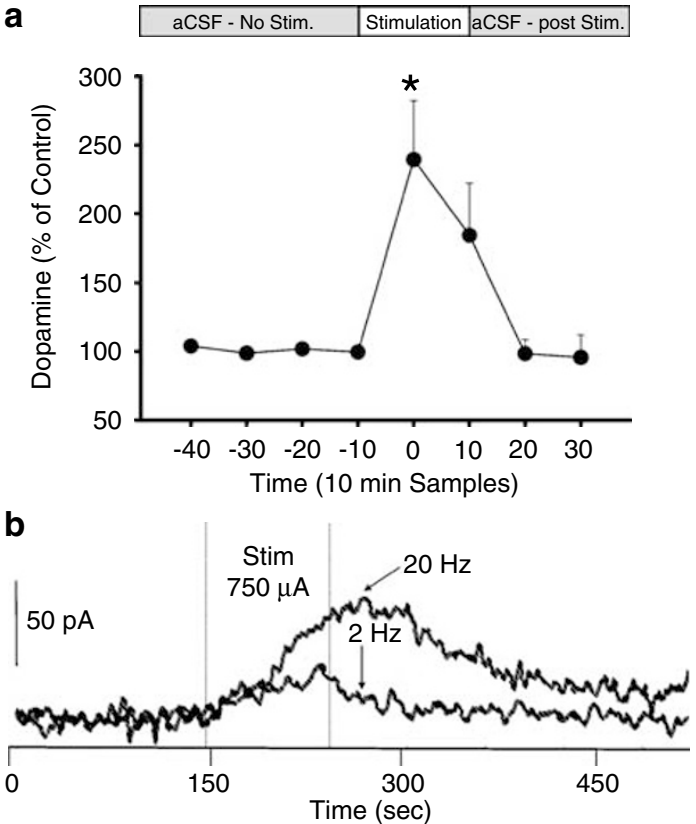

C

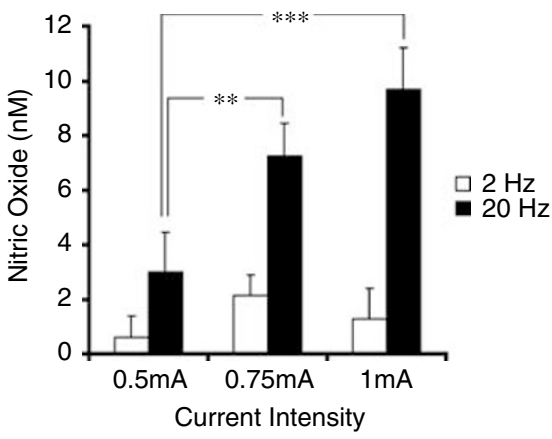

Figure 3 High-frequency stimulation of SN robustly increases DA and $\mathrm{NO}$ efflux in vivo. (a) Dialysate samples were collected every 10 min during the prestimulation $(-40$ to -10$)$, stimulation $0(20 \mathrm{~Hz}, 800 \mathrm{~ms}$ train duration, $5 \mathrm{~s} \mathrm{ITI}, 1000 \mu \mathrm{A}, 0.5 \mathrm{~ms}$ pulse duration), and poststimulation periods (10-30). High-frequency SN stimulation significantly increased striatal DA efflux over basal levels ( $p<0.05$, RM-ANOVA with Bonferroni t-test, $n=4$ ). Basal extracellular DA levels were $2.40 \pm 0.6 \mathrm{fmol} / \mu \mathrm{l}$ (mean \pm SEM). (b) A representative recording showing the $\mathrm{NO}$ oxidation signal during the prestimulation (0-150 s), stimulation (I50-250 s), and the poststimulation (250-500 s) periods. (c) High-frequency stimulation ( $100 \mathrm{~s}$, $20 \mathrm{~Hz}$ at $500,750,1000 \mu \mathrm{A}, 0.5 \mathrm{~ms}, 5 \mathrm{~s}$ ITI) significantly increased $(p<0.00$ I, two-way ANOVA-RM, $n=9)$ striatal NO efflux over levels evoked during low-frequency $(2 \mathrm{~Hz})$ stimulation at the higher current intensities $(750-1000 \mu \mathrm{A}$ at $20 \mathrm{~Hz})$. The magnitude of $\mathrm{NO}$ efflux evoked by $\mathrm{SN}$ stimulation $(750-1000 \mu \mathrm{A}, 20 \mathrm{~Hz})$ was significantly greater than that evoked by the lower intensity $(500 \mu \mathrm{A}, 20 \mathrm{~Hz}(* * p<0.0$ l, **** $p<0.00 \mathrm{I}$, two-way ANOVA-RM, $n=9)$ ). Extracellular NO levels following the $2 \mathrm{~Hz}$ stimulation were: $0.6 \pm 0.8 \mathrm{nM}, 2.1 \pm 0.8 \mathrm{nM}$, and $1.3 \pm 1.1 \mathrm{nM}$ at 500,750 , and $1000 \mu \mathrm{A}$, respectively. Following train stimulation of the $\mathrm{SN}$, extracellular NO levels were: $3.0 \pm 1.5 \mathrm{nM}, 7.2 \pm 1.2 \mathrm{nM}$, and $9.7 \pm 1.5 \mathrm{nM}$ at 500,750, and $1000 \mu \mathrm{A}$, respectively. Results are expressed as the mean \pm SEM.

efflux was transient and reproducible over time (15-30 min intervals between S1 and S2 stimulation periods) in animals anesthetized with either chloral hydrate or urethane (Figure $4 ; p>0.05)$. Furthermore, the mean magnitude of responses evoked in chloral hydrate $(400 \mathrm{mg} / \mathrm{kg}$, i.p.)- and urethane $(1.5 \mathrm{~g} / \mathrm{kg}$, i.p.)-anesthetized rats was not significantly different (Figure $4, p>0.05$ ). 
Systemic Administration of NOS Inhibitors Attenuates the SN Stimulation-Induced Increase in NO Efflux

Systemic administration of vehicle (Cremophor EL in $0.9 \%$. Saline, i.p.) alone did not alter the NO response to train stimulation of the SN (Figure $5 \mathrm{a}, \mathrm{b} ; p>0.05$ ). Systemic administration of the neuronal NOS inhibitor 7-NI $(25 \mathrm{mg} / \mathrm{kg}$, i.p.) attenuated the increase in $\mathrm{NO}$ oxidation current evoked during $\mathrm{SN}$ train stimulation (Figure $5 \mathrm{c}$, d; $p<0.01)$. These studies indicate that the increase in NO efflux observed during SN stimulation was derived largely from neuronal sources of NO. Systemic administration ( $\sim 45 \mathrm{~min})$ of the nonspecific NOS inhibitor MB $(10 \mathrm{mg} / \mathrm{kg}$, i.p.) also attenuated the $\mathrm{NO}$ response associated with $\mathrm{SN}$

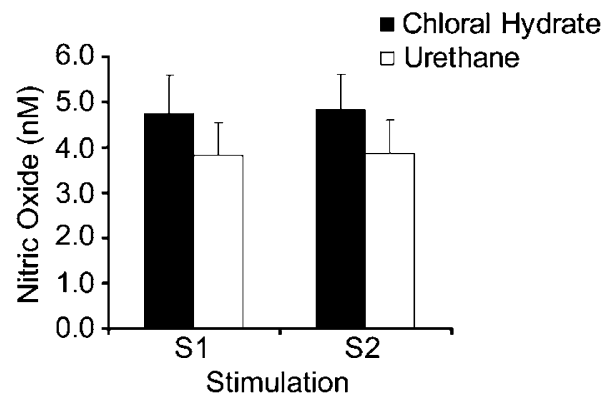

Figure 4 Effect of repeated SN stimulation on $\mathrm{NO}$ efflux in chloral hydrate- and urethane-anesthetized rats. The increase in NO oxidation signal evoked by train stimulation $(750 \mu \mathrm{A})$ of the SN was not significantly different when repeated I5-30 min after the first stimulation trial. Also, no significant differences in $\mathrm{NO}$ efflux were observed during $\mathrm{SN}$ stimulation in chloral hydrate (SI: $4.7 \pm 0.8 \mathrm{nM}$; S2: $4.8 \pm 0.8 \mathrm{nM}$ ) compared to urethane (SI: $3.8 \pm 0.7$; $S 2: 3.9 \pm 0.7 \mathrm{nM}$ )-anesthetized rats ( $p>0.05$, two-way RMANOVA, chloral hydrate: $n=20$; urethane: $n=16$ ). Results are expressed as the mean \pm SEM. a

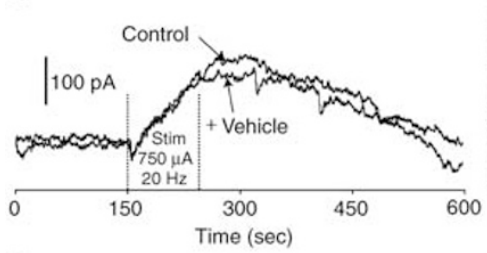

C

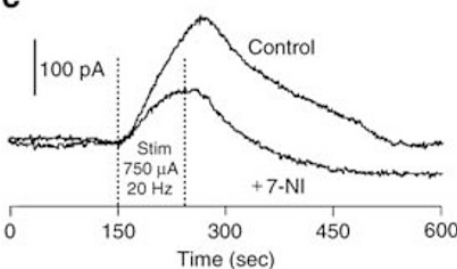

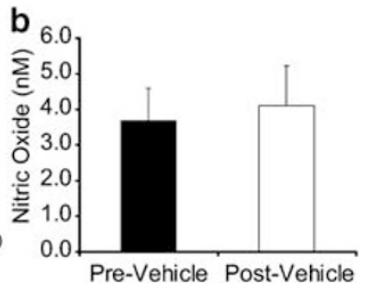

d

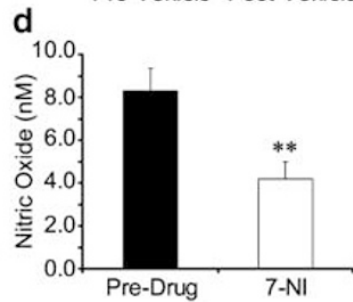

Figure 5 Systemic administration of a neuronal NOS inhibitor attenuates striatal NO efflux evoked during electrical stimulation of the $\mathrm{SN}$. (a) Representative recording showing the effect of high-frequency stimulation ( $100 \mathrm{~s}, 20 \mathrm{~Hz}, 750 \mu \mathrm{A}, 0.5 \mathrm{~ms})$ of the $\mathrm{SN}$ prior to and following administration of vehicle (10\% cremophor EL in $0.9 \%$ saline). (b) Vehicle administration did not alter $\mathrm{NO}$ efflux (pre-vehicle: $3.7 \pm 0.9 \mathrm{nM}$, postvehicle: $4.1 \pm 1.1 \mathrm{nM} ; p>0.05$, paired t-test, $n=4$ ). (c) Representative recording showing the effect of high-frequency stimulation of the $\mathrm{SN}$ following (30-60 min) systemic administration of 7-NI (25 mg/kg, i.p.). (d) Striatal NO efflux evoked during SN stimulation was significantly reduced (pre-drug: $8.3 \pm 1.0 \mathrm{nM}$, post-7-NI: $4.2 \pm 0.8$; *** $p<0.0 \mathrm{I}$, paired $t$-test, $n=7)$ following 7-NI administration. Results are expressed as the mean \pm SEM. train stimulation (pre-MB: $1.6 \pm 0.3 \mathrm{nM}$; post-MB: $0.5 \pm$ $0.3 \mathrm{nM} ; N=5$, paired $t$-test, $p<0.01$ ). In multiple cases, $\mathrm{NO}$ efflux evoked by $\mathrm{SN}$ stimulation was observed to return towards pre-MB levels approximately $90 \mathrm{~min}$ after the $\mathrm{MB}$ injection (data not shown).

Systemic Administration of a $\mathrm{D}_{1 / 5}$ Receptor Antagonist Attenuates NO Efflux Induced by Electrical Stimulation of the SN

In order to examine the potential involvement of DA $\mathrm{D}_{1 / 5}$ receptors in mediating the effects of SN stimulation on striatal NO efflux, SN stimulation was carried out as described above prior to and following (30-60 min) systemic administration of SCH $23390(100 \mu \mathrm{g} / \mathrm{kg}$, i.p). The increase in NO efflux observed during high-frequency SN stimulation $(20 \mathrm{~Hz}, 800 \mathrm{~ms}$ train duration, $5 \mathrm{~s}$ ITI; $0.75 \mathrm{~mA})$ was nearly abolished following systemic administration of the DA $\mathrm{D}_{1 / 5}$ receptor antagonist SCH 23390 (Figure 6a, b; $p<0.05)$.

Systemic Administration of a $D_{1 / 5}$ Receptor Antagonist Attenuates NO Efflux Induced by Chemical Stimulation of the SN

Additional studies were performed using microinjections of BIC (200 ng) into the SN in order to determine the impact of chemical stimulation of this region on striatal NO efflux. These experiments were performed in control rats (no drug treatment) or animals administered SCH $23390(500 \mu \mathrm{g} / \mathrm{kg}$, i.p) prior to $(15-20 \mathrm{~min})$ the intra nigral $\mathrm{BIC}$ infusion. In control animals, microinjection of BIC into the $\mathrm{SN}$
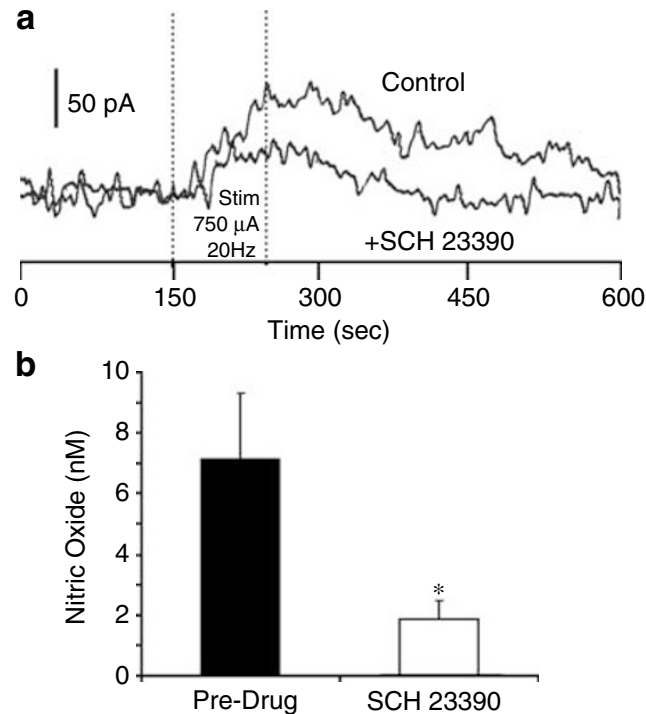

Figure 6 Systemic administration of a $D_{1 / 5}$ receptor antagonist attenuates striatal $\mathrm{NO}$ efflux evoked during electrical stimulation of the $\mathrm{SN}$. (a) A representative recording showing the effects of high-frequency stimulation $(100 \mathrm{~s}, 20 \mathrm{~Hz}, 750 \mu \mathrm{A}, 0.5 \mathrm{~ms})$ under control conditions and following (30-60 min) systemic administration of SCH $23390(0.1 \mathrm{mg} / \mathrm{kg}$, i.p.). (b) The mean $\pm \mathrm{SEM}$ increase in $\mathrm{NO}$ release evoked by train stimulation $(750 \mu \mathrm{A})$ was significantly reduced following SCH 23390 treatment (pre-drug: $7.1 \pm 2.2 \mathrm{nM}$; post-SCH 23390: $1.9 \pm 0.6$; $* 0<0.05$, paired $t$-test, $n=6)$. 
produced a robust and sustained increase in striatal NO efflux (Figure $7 \mathrm{a}, \mathrm{b}$ ). In contrast with control animals, subjects pretreated with SCH 23390 exhibited significantly smaller increases in NO efflux following identical intranigral BIC infusions (Figure 7a, b; $p<0.05$ ). Intra-nigral administration of vehicle ( $0.9 \%$ saline) did not significantly alter NO oxidation currents (data not shown). These observations are consistent with the above studies using electrical stimulation of the SN and indicate that DA $D_{1 / 5}$ receptors are critically involved in mediating the effect of SN stimulation on striatal NO efflux.

\section{Impact of DA $\mathrm{D}_{1 / 5}$ Receptor Agonism on Striatal NO Synthesis In Vivo}

In order to further examine the involvement of $\mathrm{D}_{1 / 5}$ receptor activation in facilitating striatal NO efflux, NO oxidation current was recorded prior to and immediately following systemic administration of the selective $D_{1 / 5}$ receptor agonist SKF $81297(50 \mu \mathrm{g} / \mathrm{kg}$, i.v. $)$. In all animals, the responsiveness of the $\mathrm{NO}$ microsensor to high-frequency $\mathrm{SN}$ stimulation $(20 \mathrm{~Hz}, 800 \mathrm{~ms}$ train duration, $5 \mathrm{~s}$ ITI; $0.75 \mathrm{~mA})$ was tested (2-3 separate trials) prior to administration of SKF 81297 in order to verify that the NO microsensor was positioned appropriately in the DA terminal field and confirm the stability of the evoked response (Figure 8a). Systemic administration of SKF 81297 induced a sustained increased in striatal NO efflux (Figure 8a,b). The SKF 81297-induced increase in NO oxidation current lasted

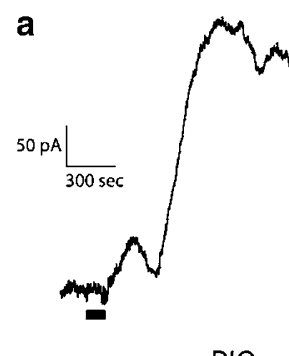

BIC

b

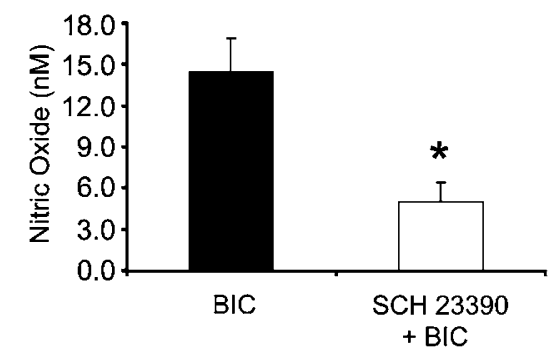

Figure 7 Systemic administration of a $D_{1 / 5}$ receptor antagonist attenuates striatal $\mathrm{NO}$ efflux evoked during chemical stimulation of the $\mathrm{SN}$. (a) Two representative recordings showing $\mathrm{NO}$ efflux following intranigral administration of bicuculline (BIC, $200 \mathrm{ng} / \mathrm{I} \mu / 2 \mathrm{~min}$ ) in the absence (left) and presence (right) of the $D_{1 / 5}$ antagonist SCH $23390(500 \mu \mathrm{g} / \mathrm{kg}$ i.p.). The black bar underneath traces indicates the period during which $\mathrm{BIC}$ was being administered. (b) Systemic administration of the $D_{1 / 5}$ antagonist $\mathrm{SCH} 23390$ significantly attenuated the $\mathrm{NO}$ efflux associated with intranigral administration of the $\mathrm{GABA}_{\mathrm{A}}$ antagonist $\mathrm{BIC}(\mathrm{BIC}: 14.5 \pm 2.5 \mathrm{nM}$; SCH $23390+$ BIC: $5.0 \pm 1.4 n M ; p<0.05$, unpaired $t$-test, $n=5)$. Results are expressed as the mean \pm SEM. between 12 and $30 \mathrm{~min}$ and peaked around $2-4 \mathrm{~min}$ from the time of the injection (Figure 8, inset). Moreover, the SKF 81297-induced effect was blocked in the same animals (Figure $8 \mathrm{a}, \mathrm{b} ; p<0.05$ ) by systemic administration of the DA $\mathrm{D}_{1 / 5}$ receptor antagonist SCH $23390(100 \mu \mathrm{g} / \mathrm{kg}$, i.p).

\section{DISCUSSION}

This study investigated the impact of SN stimulation designed to mimic DA cell burst firing on striatal NO synthesis and the role of $\mathrm{DA} \mathrm{D}_{1 / 5}$ receptor activation in mediating this response. A major finding of our study is that NO efflux is stimulated in vivo in a frequency- and stimulus intensity-dependent manner following SN train stimulation. Train stimulation also increased striatal extracellular DA levels indicating that this stimulation paradigm was effective in driving the nigrostriatal DA system. Systemic administration of the nNOS inhibitor 7-NI attenuated the SN stimulation-induced increase in NO efflux indicating that the effect was largely dependent on neuronal sources of NO. Furthermore, NO efflux evoked by electrical and chemical SN stimulation was attenuated

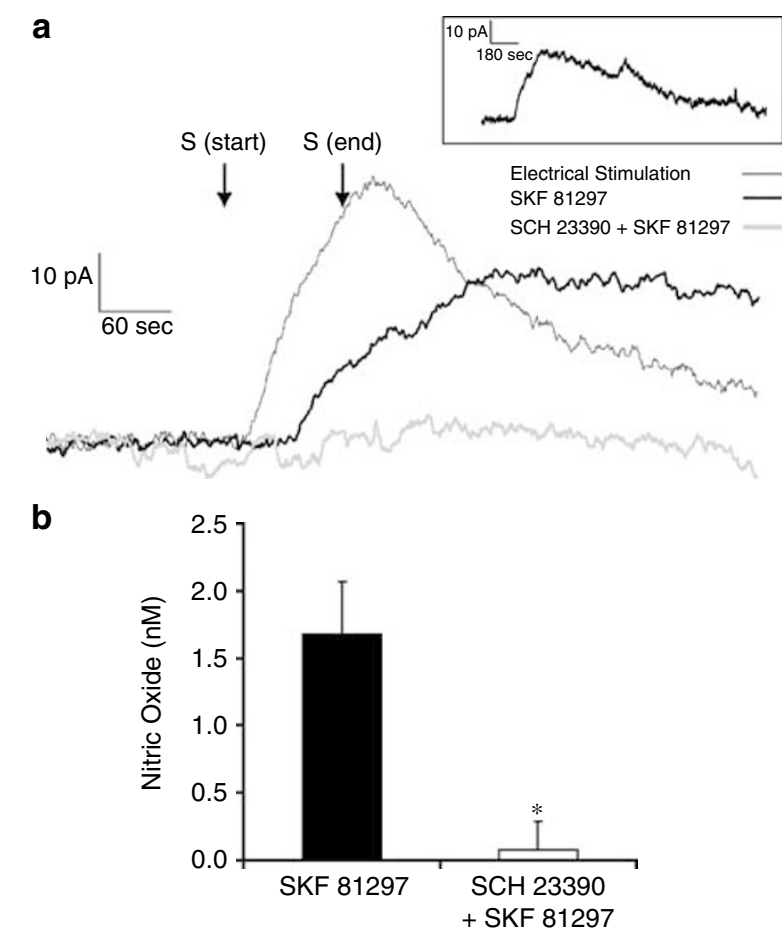

Figure 8 Systemic administration of $D_{1 / 5}$ receptor agonist facilitates NO efflux in the striatum in a manner which is blocked by the administration of $D_{1 / 5}$ antagonist. (a) $A$ representative recording showing $\mathrm{NO}$ efflux following $\mathrm{SN}$ train stimulation (-, $100 \mathrm{~s}, 20 \mathrm{~Hz}, 750 \mu \mathrm{A}, 0.5 \mathrm{~ms}$ ), administration of SKF $81297(-, 50 \mu \mathrm{g} / \mathrm{kg}$ i.v.), and following coadministration of SKF 81297 and SCH 23390 (_, $50 \mu \mathrm{g} / \mathrm{kg}$ i.v. $+100 \mu \mathrm{g} / \mathrm{kg}$, i.p., respectively) in the same animal. The inset depicts the full duration of the same response to SKF 81297. (b) Intravenous administration of the $D_{1 / 5}$ receptor agonist SKF 81297 induced an increase $(1.7 \pm 0.4 \mathrm{nM})$ in $\mathrm{NO}$ efflux in the striatum. This increase was blocked following the intraperitoneal administration of the $D_{1 / 5}$ receptor antagonist $\mathrm{SCH} 23390$ $\left(0.1 \pm 0.2 \mathrm{nM} ; *^{*} p<0.05\right.$, paired $t$-test, $\left.n=5\right)$. $S($ start $)=$ start of $S N$ stimulation; $\mathrm{S}(\mathrm{end})=$ end of $\mathrm{SN}$ stimulation. Results are expressed as the mean \pm SEM. 
following systemic administration of the $\mathrm{D}_{1 / 5}$ antagonist $\mathrm{SCH} 23390$. When taken together with the observation that systemic administration of the $\mathrm{D}_{1 / 5}$ agonist SKF 81297 increased NO efflux in a manner which was also blocked by SCH 23390 pretreatment, these findings provide strong evidence that phasic DA transmission activates striatal nNOS in vivo via a $\mathrm{D}_{1 / 5}$ receptor-dependent mechanism.

\section{Technical Considerations}

Since our experiments involved repeated stimulation and were carried out in anesthetized rats, we investigated whether the NO efflux in response to SN stimulation was altered by time and type of anesthesia. The data shown in Figure 4 confirm that the NO oxidation current produced during repeated $\mathrm{SN}$ train stimulation is relatively stable over time. Furthermore, the results depicted in Figure 4 indicate that the observed response to $\mathrm{SN}$ stimulation was not significantly different in rats anesthetized with chloral hydrate or urethane.

Given that all experiments in the current study were performed in intact animals and all drugs (except BIC) were delivered systemically, it is unclear whether $D_{1 / 5}$ receptormediated activation of NOS activity occurs directly at the level of the striatal NOS interneuron or through an indirect circuit. Since the activation of $\mathrm{D}_{1 / 5}$ receptors stimulates cholinergic interneurons (Aosaki et al, 1998) that have reciprocal connections with NOS interneurons (Vuillet et al, 1992), the potential role of this and other indirect circuits in the $\mathrm{D}_{1 / 5}$-mediated facilitation of NOS activity needs to be assessed in future studies. Moreover, high-frequency electrical stimulation of the $\mathrm{SN}$ can activate fibers of passage in the midbrain, and potentially, antidromically activate corticospinal neurons which also send axon collaterals to the striatum (Wilson, 2004). Thus, it is conceivable that indirect activation of glutamatergic pathways may have contributed to the effects of SN stimulation on striatal NOS activity. This possibility appears unlikely, however, given our observations that local chemical stimulation of the SN with BIC, which is known to induce burst firing in DA neurons (Tepper et al, 1995; Paladini and Tepper, 1999), was also shown to increase striatal NO efflux via a $\mathrm{D}_{1 / 5}$-mediated mechanism.

\section{Phasic DA Transmission Induces a Robust Increase in Striatal NO Efflux In Vivo}

The current results indicate that the phasic increase in DA transmission evoked during electrical and chemical stimulation of the $\mathrm{SN}$ is particularly effective in facilitating striatal NO release and suggest that information transmitted via the nigrostriatal pathway during DA cell burst firing may be processed and/or amplified by NOS interneurons. Midbrain DA neurons have been shown to exhibit two types of spontaneous discharge patterns: burst and irregular or tonic single spike firing modes (Grace and Bunney, 1984a, b; Tepper et al, 1995; Overton and Clark, 1997; Kitai et al, 1999). Burst firing has been previously shown to lead to more efficient DA release relative to single pulse stimulation applied at regular intervals (Gonon, 1988). The expression of $c$-Fos has also been shown to be selectively increased by stimuli mimicking natural burst firing, but not by low- frequency stimulation (Chergui et al, 1994, 1996). Interestingly, recordings from behaving animals have shown that burst firing in midbrain DA neurons is associated with salient and motivationally relevant stimuli (Freeman et al, 1985; Mirenowicz and Schultz, 1996; Hyland et al, 2002). Thus, phasic DA transmission arising during DA cell burst firing is thought to be the mode of DA transmission that mediates rapid, behaviorally relevant signaling across synapses in DA terminal fields (Grace, 1991). In contrast to the phasic DA signal, tonic DA transmission has been described as the pool of DA that is present at steady-state concentrations $(5-20 \mathrm{nM})$ within the extracellular space and is tightly regulated even when the DA system is compromised by 6-OHDA lesions (Grace, 1991). Tonic extracellular DA levels are sustained by DA overflow from synaptic and nonsynaptic sites during corticostriatal glutamate transmission and low-frequency single spike/population activity of midbrain DA cells (Grace, 1991; Floresco et al, 2003; West et al, 2003). The results of the current study indicate that tonic DA transmission evoked by low-frequency stimulation of the SN results in subtle changes in NO efflux. On the other hand, phasic DA transmission occurring during high frequency and chemical stimulation of the SN robustly increases NO efflux in the dorsal striatum. Taken together with recent behavioral studies (see Introduction and below), these observations suggest that dopaminergic and nitrergic systems are likely to interact in a complex manner to control purposeful and motivational behavior.

\section{SN Stimulation Induces NO Efflux via Activation of Neuronal NOS}

Systemic administration of either MB or 7-NI attenuated NO efflux evoked by SN stimulation indicating that the oxidation signal was largely dependent on NOS activation. Given that all three isoforms of the NOS enzyme can be found in the brain under normal or pathological conditions (Bredt et al, 1990; Dinerman et al, 1994; Madrigal et al, 2001), it is important to determine the source of NO evoked during SN stimulation. Previous studies using intact preparations have shown that 7-NI is a selective inhibitor of the neuronal isoform of NOS (Moore and Bland-Ward, 1996). The dose of 7-NI utilized $(25 \mathrm{mg} / \mathrm{kg}$, i.p.) in our experiments reduced NO efflux evoked by SN stimulation by approximately $50 \%$. These observations are consistent with previous studies reporting that 7-NI $(25 \mathrm{mg} / \mathrm{kg}$, i.p.) produced half-maximal inhibition $\left(\mathrm{EC}_{50}\right)$ of striatal NOS activity as assessed ex vivo (30 min postinjection; Kalisch et al, 1996) and indicate that SN stimulation increases striatal NO efflux via an nNOS-dependent mechanism.

NO signaling generated from nNOS has been intricately linked to locomotor activity. Thus, nNOS inhibitors have been shown to block or decrease basal locomotor activity (Stewart et al, 1994) and the behavioral effects of various psychoactive drugs including phencylclidine, methylphenidate, nicotine, methamphetamine, cocaine, amphetamine, apomorphine, morphine, caffeine, and ethanol (Itzhak, 1997; Przegalinski and Filip, 1997; Itzhak and Martin, 2000, 2002; Li et al, 2002a, b; Zarrindast et al, 2003; Shin et al, 2003; Ulusu et al, 2005; Kayir and Uzbay, 2004; Klamer et al, 2004a, b). On the other hand, the administration of L-arginine and NO generators has been reported to 
increase morphine- (Shin et al, 2003), amphetamine-, and cocaine-induced hyperlocomotion (Przegalinski and Filip, 1997). Additional studies have shown that cocaine- and methamphetamine-induced sensitization is abolished in nNOS(-I-) mice (Itzhak et al, 1998a, b). Furthermore, direct DA agonist-induced locomotor activity, including that of the $D_{1 / 5}$ agonist SKF 38393, has been shown to be attenuated or potentiated by nNOS inhibition (7-NI) and NO donor (molsidomine) administration, respectively (Przegalinski and Filip, 1997). NOS inhibitors have also been shown to reduce movement stimulated by $D D_{1}$ and $\mathrm{D}_{2}$ agonists (Starr and Starr, 1995), while $\mathrm{D}_{2}$ antagonistinduced catalepsy was potentiated (Cavas and Navarro, 2002).

\section{SN Stimulation Increases NO Efflux via a $D_{1 / 5}$ Receptor-Dependent Mechanism}

To shed more light on the interaction between dopaminergic and nitrergic systems, we investigated the role of DA $\mathrm{D}_{1 / 5}$ receptor activation in mediating $\mathrm{SN}$-induced striatal NO efflux. The $\mathrm{D}_{1 / 5}$ antagonist SCH 23390 was observed to attenuate NO efflux evoked by both electrical (train) and chemical SN stimulation. A role for $\mathrm{D}_{1 / 5}$ receptor activation in stimulating striatal nNOS activity and inducing NO release was also supported by the observation that intravenous administration of the selective $\mathrm{D}_{1 / 5}$ agonist SKF 81297 (in the absence of SN stimulation) induced an increase in NO release, which was blocked in the same animals by SCH 23390. This effect was observed in animals which also exhibited increases in NO efflux during train stimulation of the SN, indicating that NOS neurons are activated by endogenous $\mathrm{DA}$ and $\mathrm{D}_{1 / 5}$ agonist in these rats. These results extend previous histochemical studies showing that NOS activity, assayed via NADPH-diaphorase staining, is reduced following the administration of the $\mathrm{D}_{1 / 5}$ antagonist SCH 23390 (Morris et al, 1997). Consistent with our findings, $\mathrm{D}_{1 / 5}$ agonist administration has been shown to robustly stimulate the firing activity of electrophysiologically identified NOS interneurons in a manner sensitive to SCH 23390 administration (Centonze et al, 2002). Moreover, given that SKF 38393 depolarized the membrane of NOS cells in the presence of TTX, it is likely that DA exerts the majority of its facilitatory affects via a direct $\mathrm{D}_{1 / 5}$ receptor-dependent mechanism (Centonze et al, 2002).

Indirect evidence also exists indicating that striatal D1like receptor stimulation increases NO transmission. Thus, the facilitation of striatal acetylcholine release by SKF 38393 was blocked by local infusion of a nonspecific NOS inhibitor (Steinberg et al, 1998), indicating that $\mathrm{D}_{1 / 5}$ agonist-induced increase in NO transmission may stimulate the activity of cholinergic interneurons (Centonze et al, 2001). SKF 38393 has also been shown to increase striatal tissue levels of cGMP in a manner sensitive to SCH 23390 (Altar et al, 1990). Given that striatal cGMP levels are robustly increased by NO donors (Tsou et al, 1993; Globus et al, 1995; Wykes et al, 2002), it is likely that the $\mathrm{D}_{1 / 5}$ agonist-induced increase in cGMP observed by Altar and co-workers was at least partially mediated by an indirect $\mathrm{D}_{1 / 5}$ receptor-dependent activation of striatal NOS activity.
In contrast to our findings and the above-mentioned studies, Iravani et al (1998) have reported that local pressure ejection of DA into striatal slices did not increase NO efflux as measured by fast cyclic voltammetry. It is difficult to reconcile our observations with the above study given that the authors did not include the data in their report or indicate how many attempts were made to assess the impact of exogenous DA on NO efflux. A likely explanation for these discrepant findings is the difference in electrode size/sampling area between studies. The active surface of the NO microelectrodes utilized in our study was much larger ( $200 \mu \mathrm{m}$ diameter, $4-5 \mathrm{~mm}$ length) than those utilized by Iravani et al (7 $\mu \mathrm{m}$ diameter, $20-30 \mu \mathrm{m}$ length). Thus, we were able to assess the impact of endogenous DA and $\mathrm{D}_{1 / 5}$ agonist on $\mathrm{NO}$ efflux sampled across relatively large striatal subregions.

\section{Role of Nitrergic Transmission in Striatal Function}

Ultrastructural studies have demonstrated that NOS immunoreactive processes target the dendritic spine shafts of striatal MSNs (Morello et al, 1997; Sancesario et al, 2000; Calabresi et al, 2000b; Hidaka and Totterdell, 2001). Research characterizing the subcellular localization of GC second messenger pathways downstream of these nitrergic inputs also supports a role for $\mathrm{NO}$ in regulating striatal MSN activity (Ariano, 1983; Walaas et al, 1989; Fujishige et al, 1999). NO-dependent stimulation of GC results in increased DA- and cyclic-AMP-regulated phosphoprotein32 (DARPP-32) activity in striatal slices (Nishi et al, 2005). Moreover, electrophysiological studies in vitro have demonstrated that NO efflux evoked by high-frequency stimulation of corticostriatal pathways modulates the long-term synaptic plasticity of MSNs via the activation of the GC signaling cascade and DARPP-32 (Calabresi et al, 1999a, b, 2000a, b). Our previous studies in vivo also indicate that tonic NO-GC signaling can enhance the membrane excitability of striatal neurons exhibiting electrophysiological and morphological characteristics of MSNs (West et al, 2002; West and Grace, 2004). Interestingly, a recent study demonstrated that phosphodiesterase 1B knockout mice exhibit hyperlocomotion, elevated DARPP-32 phosphorylation in response to DA $\mathrm{D}_{1 / 5}$ agonist, and spatial-learning deficits (Reed et al, 2002). Selective ablation of striatal NOS and cholinergic interneurons was also shown to alter behavioral and immediate early gene responses to DA agonists (Saka et $a l, 2002)$. Thus, $\mathrm{NO}$ and DA may act in concert to modulate the synaptic activity and membrane properties of MSNs containing GC, PKG, PKA, DARPP-32, and/or other DA signaling molecules.

Taken together, these observations indicate that a dysfunction in striatal nitrergic neurotransmission can disrupt information processing in MSNs and result in dysregulation of neurotransmission in basal ganglia circuits. In support of this, a recent study utilizing quantitative EEG methods has shown that inhibition of nNOS activity has a major impact on electrical activity patterns within corticostriatopallidal circuits (Ferraro et al, 2002). Additionally, we have observed that NO-dependent modulation of striatal neuron activity regulates the activity of DA neurons in the $\mathrm{SN}$ via striatonigral feedback pathways (West and Grace, 2000). Moreover, several studies reporting 
that measures of nNOS activity are depressed in 6-OHDAlesioned animals (de Vente et al, 2000; Sahach et al, 2000; Sancesario et al, 2004) suggest that nitrergic transmission may be compromised in patients with PD. This possibility is substantiated by studies demonstrating that striatal NOSimmunopositive cell numbers and mRNA are significantly depleted in post-mortem Parkinsonian brains (Bockelmann et al, 1994; Eve et al, 1998).

\section{Conclusions}

The current study is, to our knowledge, the first to demonstrate directly that striatal nNOS is stimulated in vivo by phasic activation of midbrain $\mathrm{DA}$ cells via a $\mathrm{DA} \mathrm{D}_{1 / 5}$ receptor-dependent mechanism. These findings are consistent with previous reports that $\mathrm{D}_{1 / 5}$ receptor activation increases indirect measures of NOS activity (Altar et al, 1990; Morris et al, 1997) and firing activity of electrophysiologically identified NOS interneurons (Centonze $e t a l$, 2002). Thus, striatal NOS interneurons may be potently activated by DA cell burst firing in specific behavioural contexts. This implicates DA-induced release of NO in the control of motivational behavior and thus suggests novel potential therapeutic targets for the treatment of neurological and psychiatric disorders.

\section{ACKNOWLEDGEMENTS}

We thank Drs Marjorie A Ariano and Marina E Wolf for their valuable assistance and comments regarding this manuscript. This work was supported by the Chicago Medical School, Parkinson's Disease Foundation, and by United States Public Health Grant NS 047452 (ARW).

\section{REFERENCES}

Altar CA, Boyar WC, Kim HS (1990). Discriminatory roles for D1 and D2 dopamine receptor subtypes in the in vivo control of neostriatal cyclic GMP. Eur J Pharmacol 181: 17-21.

Aosaki T, Kiuchi K, Kawaguchi Y (1998). Dopamine D1-like receptor activation excites rat striatal large aspiny neurons in vitro. J Neurosci 18: 5180-5190.

Ariano MA (1983). Distribution of components of the guanosine $3^{\prime}, 5^{\prime}$-phosphate system in rat caudate-putamen. Neuroscience 10: 707-723.

Berretta S, Parthasarathy HB, Graybiel AM (1997). Local release of GABAergic inhibition in the motor cortex induces Immediateearly gene expression in indirect pathway NEURONS of the striatum. J Neurosci 17: 4752-4763.

Bockelmann R, Wolf G, Ransmayr G, Riederer P (1994). NADPHdiaphorase/nitric oxide synthase containing neurons in normal and Parkinson's disease putamen. J Neural Transm Park Dis Dement Sect 7: 115-121.

Boehning D, Snyder SH (2003). Novel neural modulators. Annu Rev Neurosci 26: 105-131.

Brady AM, O'Donnell P (2004). Dopaminergic modulation of prefrontal cortical input to nucleus accumbens neurons in vivo. J Neurosci 24: 1040-1049.

Bredt DS, Glatt CE, Hwang PM, Fotuhi M, Dawson TM, Snyder SH (1991). Nitric oxide synthase protein and mRNA are discretely localized in neuronal populations of the mammalian CNS together with NADPH diaphorase. Neuron 7: 615-624.

Bredt DS, Hwang PM, Snyder SH (1990). Localization of nitric oxide synthase indicating a neural role for nitric oxide. Nature 347: 768-770.
Calabresi P, Centonze D, Gubellini P, Marfia GA, Bernardi G (1999a). Glutamate-triggered events inducing corticostriatal long-term depression. J Neurosci 19: 6102-6110.

Calabresi P, Centonze D, Gubellini P, Marfia GA, Pisani A, Sancesario G, Bernardi G (2000a). Synaptic transmission in the striatum: from plasticity to neurodegeneration. Prog Neurobiol 61: 231-265.

Calabresi P, Gubellini P, Centonze D, Picconi B, Bernardi G, Chergui K, Svenningsson P, Fienberg AA, Greengard P (2000b). Dopamine and cAMP-regulated phosphoprotein $32 \mathrm{kDa}$ controls both striatal long-term depression and long-term potentiation, opposing forms of synaptic plasticity. J Neurosci 20: 8443-8451.

Calabresi P, Gubellini P, Centonze D, Sancesario G, Morello M, Giorgi M, Pisani A, Bernardi G (1999b). A critical role of the nitric oxide/cGMP pathway in corticostriatal long-term depression. J Neurosci 19: 2489-2499.

Cavas M, Navarro JF (2002). Coadministration of -NOARG and tiapride: effects on catalepsy in male mice. Prog Neuropsychopharmacol Biol Psychiatry 26: 69-73.

Centonze D, Bracci E, Pisani A, Gubellini P, Bernardi G, Calabresi P (2002). Activation of dopamine $D_{1}$-like receptors excites LTS interneurons of the striatum. Eur J Neurosci 15: 2049-2052.

Centonze D, Pisani A, Bonsi P, Giacomini P, Bernardi G, Calabresi $P$ (2001). Stimulation of nitric oxide-cGMP pathway excites striatal cholinergic interneurons via protein kinase $\mathrm{G}$ activation. J Neurosci 21: 1393-1400.

Chergui K, Nomikos GG, Mathe JM, Gonon F, Svensson TH (1996). Burst stimulation of the medial forebrain bundle selectively increases Fos-like immunoreactivity in the limbic forebrain of the rat. Neuroscience 72: 141-156.

Chergui K, Suaud-Chagny MF, Gonon F (1994). Nonlinear relationship between impulse flow, dopamine release and dopamine elimination in the rat brain in vivo. Neuroscience 62: 641-645.

Consolo S, Cassetti A, Uboldi MC (1999). The parafascicular thalamic nucleus but not the prefrontal cortex facilitates the nitric oxide/cyclic GMP pathway in rat striatum. Neuroscience 91: 51-58.

Crespi F, Campagnola M, Neudeck A, McMillan K, Rossetti Z, Pastorino A et al (2001). Can voltammetry measure nitrogen monoxide (NO) and/or nitrites? J Neurosci Methods 109: 59-70.

Crespi F, Rossetti ZL (2004). Pulse of nitric oxide release in response to activation of $N$-methyl-D-aspartate receptors in the rat striatum: rapid desensitization, inhibition by receptor antagonists, and potentiation by glycine. J Pharmacol Exp Ther 309: 462-468.

Dawson TM, Bredt DS, Fotuhi M, Hwang PM, Snyder SH (1991). Nitric oxide synthase and neuronal NADPH diaphorase are identical in brain and peripheral tissues. Proc Natl Acad Sci USA 88: 7797-7801.

Deutsch SI, Rosse RB, Paul SM, Tomasino V, Koetzner L, Morn CB et al (1996). 7-Nitroindazole and methylene blue, inhibitors of neuronal nitric oxide synthase and NO-stimulated guanylate cyclase, block MK-801-elicited behaviors in mice. Neuropsychopharmacology 15: 37-43.

de Vente J, van Ittersum MM, van Abeelen J, Emson PC, Axer H, Steinbusch HWM (2000). NO-mediated cGMP synthesis in cholinergic neurons in the rat forebrain: effects of lesioning dopaminergic or serotonergic pathways on nNOS and cGMP synthesis. Eur J Neurosci 12: 507-519.

Dinerman JL, Dawson TM, Schell MJ, Snowman A, Snyder SH (1994). Endothelial nitric oxide synthase localized to hippocampal pyramidal cells: implications for synaptic plasticity. Proc Natl Acad Sci USA 91: 4214-4218.

East SJ, Parry-Jones A, Brotchie JM (1996). Ionotropic glutamate receptors and nitric oxide synthesis in the rat striatum. NeuroReport 8: 71-75. 
Eblen F, Loschmann PA, Wullner U, Turski L, Klockgether T (1996). Effects of 7-nitroindazole, NG-nitro-arginine, and DCPPene on harmaline-induced postural tremor, $N$-methylaspartate-induced seizures, and lisuride-induced rotations in rats with nigral 6-hydroxydopamine lesions. Eur J Pharmacol 299: 9-16.

Eve DJ, Nisbet AP, Kingsbury AE, Hewson EL, Daniel SE, Lees AJ et al (1998). Basal ganglia neuronal nitric oxide synthase mRNA expression in Parkinson's disease. Brain Res Mol Brain Res 63: $62-71$

Ferraro G, Sardo P, Di Giovanni G, Galati S, La Grutta V (2002). Nitric oxide and cortico-striato-pallidal motor circuitry: quantitative EEG analysis of surface and depth recordings. Neurosci Res Commun 30: 121-133.

Floresco SB, Grace AA (2003). Gating of hippocampal-evoked activity in prefrontal cortical neurons by inputs from the mediodorsal thalamus and ventral tegmental area. J Neurosci 23: 3930.

Floresco SB, West AR, Ash B, Moore H, Grace AA (2003). Afferent modulation of dopamine neuron firing differentially regulates tonic and phasic dopamine transmission. Nat Neurosci 6: 968-973.

Freeman AS, Meltzer LT, Bunney BS (1985). Firing properties of substantia nigra dopaminergic neurons in freely moving rats. Life Sci 36: 1983-1994.

Fujishige K, Kotera J, Omori K (1999). Striatum- and testis-specific phosphodiesterase PDE10A: isolation and characterization of a rat PDE10A. Eur J Biochem 266: 1118-1127.

Fujiyama F, Masuko S (1996). Association of dopaminergic terminals and neurons releasing nitric oxide in the rat striatum: an electron microscopic study using NADPH-diaphorase histochemistry and tyrosine hydroxylase immunohistochemistry. Brain Res Bull 40: 121-127.

Globus MY, Prado R, Busto R (1995). Ischemia-induced changes in extracellular levels of striatal cyclic GMP: role of nitric oxide. NeuroReport 6: 1909-1912.

Gonon F (1997). Prolonged and extrasynaptic excitatory action of dopamine mediated by D1 receptors in the rat striatum in vivo. J Neurosci 17: 5972.

Gonon FG (1988). Nonlinear relationship between impulse flow and dopamine released by rat midbrain dopaminergic neurons as studied by in vivo electrochemistry. Neuroscience 24: 19-28.

Grace AA (1991). Phasic versus tonic dopamine release and the modulation of dopamine system responsivity: a hypothesis for the etiology of schizophrenia. Neuroscience 41: 1-24.

Grace AA, Bunney BS (1984a). The control of firing pattern in nigral dopamine neurons: burst firing. J Neurosci 4: 2877-2890.

Grace AA, Bunney BS (1984b). The control of firing pattern in nigral dopamine neurons: single spike firing. J Neurosci 4: 2866-2876.

Harvey BH, Bester A (2000). Withdrawal-associated changes in peripheral nitrogen oxides and striatal cyclic GMP after chronic haloperidol treatment. Behav Brain Res 111: 203-211.

Hidaka S, Totterdell S (2001). Ultrastructural features of the nitric oxide synthase-containing interneurons in the nucleus accumbens and their relationship with tyrosine hydroxylase-containing terminals. J Comp Neurol 431: 139-154.

Hyland BI, Reynolds JNJ, Hay J, Perk CG, Miller R (2002). Firing modes of midbrain dopamine cells in the freely moving rat. Neuroscience 114: 475-492.

Iravani MM, Millar J, Kruk ZL (1998). Differential release of dopamine by nitric oxide in subregions of rat caudate putamen slices. J Neurochem 71: 1969-1977.

Itzhak Y (1997). Modulation of cocaine- and methamphetamineinduced behavioral sensitization by inhibition of brain nitric oxide synthase. J Pharmacol Exp Ther 282: 521-527.

Itzhak Y, Ali SF, Martin JL, Black MD, Huang PL (1998a). Resistance of neuronal nitric oxide synthase-deficient mice to cocaine-induced locomotor sensitization. Psychopharmacology (Berl) 140: 378-386.

Itzhak Y, Gandia C, Huang PL, Ali SF (1998b). Resistance of neuronal nitric oxide synthase-deficient mice to methamphetamine-induced dopaminergic neurotoxicity. J Pharmacol Exp Ther 284: 1040-1047.

Itzhak Y, Martin JL (2000). Blockade of alcohol-induced locomotor sensitization and conditioned place preference in DBA mice by 7-nitroindazole. Brain Res 858: 402-407.

Itzhak Y, Martin JL (2002). Effect of the neuronal nitric oxide synthase inhibitor 7-nitroindazole on methylphenidate-induced hyperlocomotion in mice. Behav Pharmacol 13: 81-86.

Kalisch BE, Connop BP, Jhamandas K, Beninger RJ, Boegman RJ (1996). Differential action of 7-nitro indazole on rat brain nitric oxide synthase. Neurosci Lett 219: 75-78.

Kawaguchi Y (1993). Physiological, morphological, and histochemical characterization of three classes of interneurons in rat neostriatum. J Neurosci 13: 4908-4923.

Kayir H, Uzbay IT (2004). Evidence for the role of nitric oxide in caffeine-induced locomotor activity in mice. Psychopharmacology (Berl) 172: 11-15.

Kendrick KM, Guevara-Guzman R, de la RC, Christensen J, Ostergaard K, Emson PC (1996). NMDA and kainate-evoked release of nitric oxide and classical transmitters in the rat striatum: in vivo evidence that nitric oxide may play a neuroprotective role. Eur J Neurosci 8: 2619-2634.

Kitai ST, Shepard PD, Callaway JC, Scroggs R (1999). Afferent modulation of dopamine neuron firing patterns. Curr Opin Neurobiol 9: 690-697.

Klamer D, Engel JA, Svensson L (2004a). Phencyclidine-induced behaviour in mice prevented by methylene blue. Basic Clin Pharmacol Toxicol 94: 65-72.

Klamer D, Engel JA, Svensson L (2004b). The neuronal selective nitric oxide synthase inhibitor, $N$ (omega)-propyl-L-arginine, blocks the effects of phencyclidine on prepulse inhibition and locomotor activity in mice. Eur J Pharmacol 503: 103-107.

Kubota Y, Mikawa S, Kawaguchi Y (1993). Neostriatal GABAergic interneurones contain NOS, calretinin or parvalbumin. NeuroReport 5: 205-208.

Le Moine C, Normand E, Bloch B (1991). Phenotypical characterization of the rat striatal neurons expressing the D1 dopamine receptor gene. Proc Natl Acad Sci USA 88: 4205-4209.

Li SM, Ren YH, Zheng JW (2002a). Effect of 7-nitroindazole on drug-priming reinstatement of -methamphetamine-induced conditioned place preference. Eur J Pharmacol 443: 205-206.

Li SM, Yin LL, Shi J, Lin ZB, Zheng JW (2002b). The effect of 7-nitroindazole on the acquisition and expression of -methamphetamine-induced place preference in rats. Eur J Pharmacol 435: 217-223.

Madrigal JLM, Moro MA, Lizasoain I, Lorenzo P, Castrillo A, Bosca L et al (2001). Inducible nitric oxide synthase expression in brain cortex after acute restraint stress is regulated by nuclear factor $\kappa \mathrm{B}$-mediated mechanisms. J Neurochem 76: 532-538.

Mancuso F, Calignano A, Sorrentino L (1994). Endogenous nitric oxide modulates behavioural effects elicited by substance $\mathrm{P}$ in rat. Eur J Pharmacol 271: 329-333.

Marin P, Lafon-Cazal M, Bockaert J (1992). A nitric oxide synthase activity selectively stimulated by NMDA receptors depends on protein kinase C activation in mouse striatal neurons. Eur J Neurosci 4: 425-432.

Marin P, Quignard JF, Lafon-Cazal M, Bockaert J (1993). Nonclassical glutamate receptors, blocked by both NMDA and non-NMDA antagonists, stimulate nitric oxide production in neurons. Neuropharmacology 32: 29-36.

Mirenowicz J, Schultz W (1996). Preferential activation of midbrain dopamine neurons by appetitive rather than aversive stimuli. Nature 379: 449-451. 
Moore PK, Bland-Ward PA (1996). 7-Nitroindazole: an inhibitor of nitric oxide synthase. In: Packer L (ed). Methods in Enzymology. Academic Press: New York. pp 393-398.

Morello M, Reiner A, Sancesario G, Karle EJ, Bernardi G (1997). Ultrastructural study of nitric oxide synthase-containing striatal neurons and their relationship with parvalbumin-containing neurons in rats. Brain Res 776: 30-39.

Morris BJ, Simpson CS, Mundell S, Maceachern K, Johnston HM, Nolan AM (1997). Dynamic changes in NADPH-diaphorase staining reflect activity of nitric oxide synthase: evidence for a dopaminergic regulation of striatal nitric oxide release. Neuropharmacology 36: 1589-1599.

Nathan C, Xie QW (1994). Nitric oxide synthases: roles, tolls, and controls. Cell 78: 915-918.

Nishi A, Watanabe Y, Higashi H, Tanaka M, Nairn AC, Greengard P (2005). Glutamate regulation of DARPP-32 phosphorylation in neostriatal neurons involves activation of multiple signaling cascades. Proc Natl Acad Sci USA 102: 1199-1204.

Ohta K, Rosner G, Graf R (1997). Nitric oxide generation from sodium nitroprusside and hydroxylamine in brain. NeuroReport 8: 2229-2235.

O'Shaughnessy C, Bhoola KD (1986). Comparison of the action of cholecystokinin, carbachol and vasoactive intestinal peptide on receptor-activated formation of cyclic GMP and cyclic AMP in the striatum and the pancreas. Biochem Pharmacol 35: 4049-4052.

Overton PG, Clark D (1997). Burst firing in midbrain dopaminergic neurons. Brain Res Brain Res Rev 25: 312-334.

Paladini CA, Tepper JM (1999). GABA(A) and GABA(B) antagonists differentially affect the firing pattern of substantia nigra dopaminergic neurons in vivo. Synapse 32: 165-176.

Paxinos G, Watson C (1986). The Rat Brain in Stereotaxic Coordinates. Academic Press: New York.

Przegalinski E, Filip M (1997). Nitric oxide (NO) pathway and locomotor hyperactivity towards dopaminomimetics in rats. Pol J Pharmacol 49: 291-298.

Reed TM, Repaske DR, Snyder GL, Greengard P, Vorhees CV (2002). Phosphodiesterase 1B knock-out mice exhibit exaggerated locomotor hyperactivity and DARPP-32 phosphorylation in response to dopamine Agonists and display impaired spatial learning. J Neurosci 22: 5188-5197.

Reynolds JN, Hyland BI, Wickens JR (2001). A cellular mechanism of reward-related learning. Nature 413: 67-70.

Rivera A, Alberti I, Martin AB, Narvaez JA, de la CA, Moratalla R (2002). Molecular phenotype of rat striatal neurons expressing the dopamine D5 receptor subtype. Eur J Neurosci 16: 2049-2058.

Sahach VF, Baziliuk OV, Oleshko MM, Kotsiuruba OV, Bukhanevych OM, Appenzeller O (2000). The nitric oxide system in a chronic deficiency of mesostriatal dopamine: the action of nitroglycerin]. Fiziol Zh 46: 55-63.

Saka E, Iadarola M, Fitzgerald DJ, Graybiel AM (2002). Local circuit neurons in the striatum regulate neural and behavioral responses to dopaminergic stimulation. Proc Natl Acad Sci USA 99: 9004-9009.

Salin P, Kerkerian-Le GL, Heidet V, Epelbaum J, Nieoullon A (1990). Somatostatin-immunoreactive neurons in the rat striatum: effects of corticostriatal and nigrostriatal dopaminergic lesions. Brain Res 521: 23-32.

Sancesario G, Giorgi M, D'Angelo V, Modica A, Martorana A, Morello $\mathrm{M}$ et al (2004). Down-regulation of nitrergic transmission in the rat striatum after chronic nigrostriatal deafferentation. Eur J Neurosci 20: 989-1000.

Sancesario G, Morello M, Reiner A, Giacomini P, Massa R, Schoen $S$ et al (2000). Nitrergic neurons make synapses on dual-input dendritic spines of neurons in the cerebral cortex and the striatum of the rat: implication for a postsynaptic action of nitric oxide. Neuroscience 99: 627-642.
Shin IC, Kim HC, Swanson J, Hong JT, Oh KW (2003). Anxiolytic effects of acute morphine can be modulated by nitric oxide systems. Pharmacology 68: 183-189.

Starr MS, Starr BS (1995). Do NMDA receptor-mediated changes in motor behaviour involve nitric oxide? Eur J Pharmacol 272: 211-217.

Steinberg R, Souilhac J, Rodier D, Alonso R, Emonds-Alt X, Le FG et al (1998). Facilitation of striatal acetylcholine release by dopamine D1 receptor stimulation: involvement of enhanced nitric oxide production via neurokinin-2 receptor activation. Neuroscience 84: 511-518.

Stewart J, Deschamps SE, Amir S (1994). Inhibition of nitric oxide synthase does not block the development of sensitization to the behavioral activating effects of amphetamine. Brain Res 641: 141-144.

Stuehr DJ, Kwon NS, Nathan CF, Griffith OW, Feldman PL, Wiseman J (1991). N-omega-hydroxy-L-arginine is an intermediate in the biosynthesis of nitric oxide from L-arginine. J Biol Chem 266: 6259-6263.

Tepper JM, Martin LP, Anderson DR (1995). GABAA receptormediated inhibition of rat substantia nigra dopaminergic neurons by pars reticulata projection neurons. J Neurosci 15: 3092-3103.

Tsou K, Snyder GL, Greengard P (1993). Nitric oxide/cGMP pathway stimulates phosphorylation of DARPP-32, a dopamineand cAMP-regulated phosphoprotein, in the substantia nigra. Proc Natl Acad Sci USA 90: 3462-3465.

Ulusu U, Uzbay IT, Kayir H, Alici T, Karakas S (2005). Evidence for the role of nitric oxide in nicotine-induced locomotor sensitization in mice. Psychopharmacology (Berl) 178: 500-504.

Vincent SR (1994). Nitric oxide: a radical neurotransmitter in the central nervous system. Prog Neurobiol 42: 129-160.

Volke V, Wegener G, Vasar E, Rosenberg R (1999). Methylene blue inhibits hippocampal nitric oxide synthase activity in vivo. Brain Res 826: 303-305.

Vuillet J, Dimova R, Nieoullon A, Goff LK-L (1992). Ultrastructural relationships between choline acetyltransferase- and neuropeptide Y-containing neurons in the rat striatum. Neuroscience 46: $351-360$.

Vuillet J, Kerkerian L, Kachidian P, Bosler O, Nieoullon A (1989). Ultrastructural correlates of functional relationships between nigral dopaminergic or cortical afferent fibers and neuropeptide Y-containing neurons in the rat striatum. Neurosci Lett 100: 99-104.

Walaas SI, Girault JA, Greengard P (1989). Localization of cyclic GMP-dependent protein kinase in rat basal ganglia neurons. J Mol Neurosci 1: 243-250.

Wegener G, Volke V, Rosenberg R (2000). Endogenous nitric oxide decreases hippocampal levels of serotonin and dopamine in vivo. Br J Pharmacol 130: 575-580.

West AR, Floresco SB, Charara A, Rosenkranz JA, Grace AA (2003). Electrophysiological interactions between striatal glutamatergic and dopaminergic systems. Ann NY Acad Sci 1003: 53-74.

West AR, Galloway MP, Grace AA (2002). Regulation of striatal dopamine neurotransmission by nitric oxide: effector pathways and signaling mechanisms. Synapse 44: 227-245.

West AR, Grace AA (2000). Striatal nitric oxide signaling regulates the neuronal activity of midbrain dopamine neurons in vivo. J Neurophysiol 83: 1796-1808.

West AR, Grace AA (2002). Opposite influences of endogenous dopamine $\mathrm{D} 1$ and $\mathrm{D} 2$ receptor activation on activity states and electrophysiological properties of striatal neurons: studies combining in vivo intracellular recordings and reverse microdialysis. J Neurosci 22: 294-304.

West AR, Grace AA (2004). The nitric oxide-guanylyl cyclase signaling pathway modulates membrane activity states and 
electrophysiological properties of striatal medium spiny neurons recorded in vivo. J Neurosci 24: 1924-1935.

Wilson CJ (2004). Basal Ganglia. In: Shepherd G (ed). The Synaptic Organization of the Brain. Oxford University Press: Oxford. pp 361-414.

Wykes V, Bellamy TC, Garthwaite J (2002). Kinetics of nitric oxidecyclic GMP signalling in CNS cells and its possible regulation by cyclic GMP. J Neurochem 83: 37-47.
Zarrindast MR, Gholami A, Sahraei H, Haeri-Rohani A (2003). Role of nitric oxide in the acquisition and expression of apomorphine- or morphine-induced locomotor sensitization. Eur J Pharmacol 482: 205-213.

Zhang X (2004). Real time and in vivo monitoring of nitric oxide by electrochemical sensors - from dream to reality. Front Biosci 9: 3434-3446. 